\title{
Problematika Hasil Belajar Matematika Pada Pembelajaran Tatap Muka Terbatas Pandemi Covid- 19 Ditinjau Dari Lingkungan Belajar
}

\author{
Yesi Ulfah Fauziah ${ }^{*}$, Nani Ratnaningsih ${ }^{2}$ \\ ${ }^{1}$ Mahasiswa Pendidikan Matematika, Pascasarjana, Universitas Siliwangi, Tasikmalaya \\ ${ }^{2}$ Dosen Pendidikan Matematika, Pascasarjana, Universitas Siliwangi, Tasikmalaya \\ yesiulfah@gmail.com
}

\begin{abstract}
The aim of this research is to know about the problematic of the students' learning outcome in limited directly learning at the covid-19 pandemic which looked by the learning environment. This research is descriptive method with qualitative approach. The subjects of this research are 4 students in $9^{\text {th }}$ grade at SMP Terpadu Miftahul Khoir which have high and low ability. 2 students live in Islamic Boarding School, and 2 students don't live in it. The test appropriates to cognitive Taxonomy Bloom Revise. The technique to take the sample is Purposive sampling. The instruments of this research are mathematic test, questionnaire, and interview. The techniques of data analysis are data reduction, data presentation, and conclusion. The result of this research is the students cannot use the facility well. The students which have high ability can achieve the indicator of understanding and applying, but cannot know how to finish the non-routine exercises. And the low ability students cannot finish the understanding and applying indicator exercises.
\end{abstract}

Keywords: learning achievement; learning environment; limited directly learning.

\begin{abstract}
Abstrak
Penelitian ini bertujuan untuk mengetahui problematika hasil belajar siswa pada pembelajaran tatap muka terbatas dimasa pandemi covid-19 yang ditinjau dari lingkungan belajar. Penelitian ini merupakan penelitian deskriptif dengan pendekatan kualitatif. Subjek penelitian ini adalah 2 orang siswa kelas IX SMP Terpadu Miftahul Khoir yang memiliki kemampuan tinggi dan rendah yang tinggal di lingkungan pondok pesantren, dan 2 orang siswa kelas IX yang memiliki kemampuan tinggi dan rendah yang tidak tinggal di lingkungan pondok pesantren yang diambil dari nilai siswa yang didapat dari tes yang disesuaikan dengan ranah kognitif Taksonomi Bloom Revisi. Teknik pengambilan sampel dengan purposive sampling. Instrumen yang digunakan yaitu tes matematika, angket, dan wawancara. Teknik analisis data yaitu, reduksi data, penyajian data, dan penarikan kesimpulan. Hasil penelitian siswa dengan kemampuan tinggi maupun rendah sudah memiliki lingkungan belajar yang baik, namun siswa belum menggunakan fasilitas belajar dengan baik. Untuk hasil belajar siswa dengan kemampuan tinggi sudah mencapai indikator memahami dan menerapkan, tetapi belum mampu menyelesaikan soal non rutin, dan siswa dengan kemampuan rendah tidak mampu mengerjakan soal dengan indikator memahami dan menerapkan dengan baik.
\end{abstract}

Kata Kunci: hasil belajar matematika; lingkungan belajar; pembelajaran tatap muka terbatas (PTMT); 


\section{PENDAHULUAN}

Sejak adanya Pandemi Covid-19, Pendidikan di Indonesia merasakan dampak yang cukup fatal, namun kegiatan belajar mengajar tidak boleh terhenti. Kegiatan belajar mengajar terpaksa harus dilakukan meskipun dilakukan dalam jarak jauh. Sesuai edaran Kemdikbud Nomor 4 Tahun 2020 bahwa pembelajaran selama pandemic dilakukan secara daring(online). Namun dari hasil penelitian Basar et,Al (2021) bahwa pelaksanaan pembelajaran jarak jauh (PJJ) menimbulkan berbagai perubahan dan tanggapan dalam system belajar dan proses belajar serta perkembangan peserta didik didik dalam menerima dan merespon materi yang disampaikan. Beberapa problematika pun muncul sebagai akibat dari pembelajarn jarak jauh selama pandemic covid-19, seperti yang di kemukakan Fadilla (2021) dalam pembelajaran matematika yang dilaksanakannya secara daring, terdapat problematika yaitu peserta didik mengalami kesulitan dalam memahami materi pembelajaran dengan baik, karena peserta didik kurang dilibatkan secara aktif.

Disusul dengan Keputusan Bersama Menteri Pendidikan dan Kebudayaan, Menteri Agama, Menteri Kesehatan, dan Menteri Dalam Negeri Republik Indonesia Nomor 03/KB/2021, Nomor 384 Tahun 2021, Nomor HK.01.08/MENKES/4242/2021, Nomor 440-717 Tahun 2021 tentang Panduan Penyelenggaraan Pembelajaran di Masa Pandemi COVID-19. Pada bulan Maret 2021, pemerintah mengeluarkan kebijakan Perberlakuan Pembatasan Kegiatan Masyarakat (PPKM), sehingga pembelajaran pun bisa dilaksanakan meskipun secara terbatas, dan Pemerintah Kota Tasikmalaya mulai mempersiapkan berbagai metode sesuai protocol Kesehatan untuk melaksanakan pembelajaran PTMT di setiap sekolah saat penerapan PPKM level 3.

Pada pembelajaran tatap muka terbatas meskipun peserta didik ada yang diberlakukan system shift atau utuh, tetapi bukan berarti pelaksanaannya sudah terlaksana dengan baik, karena ada beberapa dampak yang diakibatkan dari pembelajaran daring yang dirasakan oleh guru maupun siswa. Menurut penelitian Nissa dan Haryanto (2020) menemukan bahawa terdapat beberapa masalah yang dialami selama pembelajaran tatap muka di masa pandemic, diantaranya keterbatasan waktu pembelajaran, teknis pelaksanaan pembelajaran yang masih rancu.

Pelaksanaan pembelajaran tatap muka terbatas memang merupakan salah satu solusi di saat pandemic, namun disisi lain ada beberapa potensi masalah seperti bagaimana agar kompetensi siswa tetap terjaga. Keberhasilan belajar peserta didik merupakan bagian terpenting dalam pembelajaran yang dapat tercermin melalui hasil belajar. Hasil belajar menurut Sudjana (1995) (Husamah, 2016) adalah kemampuan yang dimilki siswa setelah menerina pengalaman belajarnya. Sedangkan menurut Salim (2002) (Husamah, 2016) hasil belajar sebagai sesuatu yang diperoleh, didapatkan atau dikuasai setelah proses belajar, biasanya situnjukkan dengan nilai atau skor. Nurhasanah (2016) hasil belajar siswa merupakan kemampuan yang ditunjukkan siswa berupa kualitas siswa sebaga dampaik dari proses pembelajaran yang telah dilaluinya. 
Dapat disumpulkan bahwa hasil belajar adalah perubahan tingkah laku sebagai hasil dari proses belajar, perubahan ini bisa meliputi, perubahan afektif, kognitif, dan psikomotorik.

Perolehan pada hasil belajar erat kaitannya dengan kemampuan peserta didik pada kawsan kognitifnya dalam memproses dan mengolah informasi pada saat belajar. Kawasan kognitif menurut Effendi (2017) ialah yang berhubungan dengan kemampuan intelektual atau kemampuan berpikir, seperti kemampuan mengingat dan kemampuan memecahkan masalah. Pada penelitian ini yang akan diteliti adalah hasil belajar berdasarkan ranah kognitif siswa berdasarkan taksonomi Anderson dan krathwohls's (2001), yang terdiri dari enam tingkatan diantaranya:

1. Remembering (recognizing, recalling)

2. Understanding (interpreting, exemplifying, classifying, infering, comparing, explaining)

3. Applying (executing, implementing)

4. Analyzing (differentiating, organizing, attributing)

5. Evaluating (checking, critiquing)

6. Creating (generating, planning, producing)

Tingkat pemahaman peserta didik dianggap berjenjang dengan tingkat paling rendah $(\mathrm{C} 1)$ : pengetahuan atau mengingat, sampai tingkat $(\mathrm{C} 6)$ : evaluasi, seperti yang digambarkan berikut :

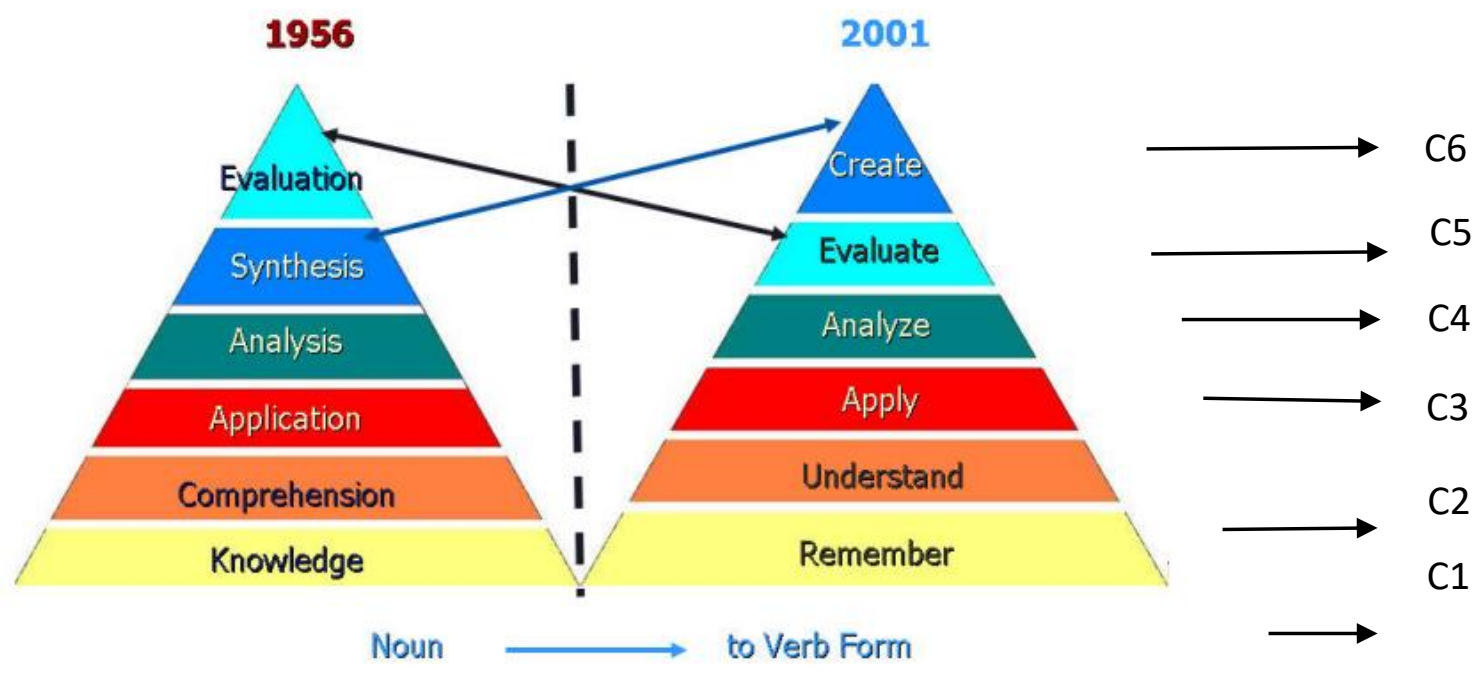

Gambar 1. Perbedaan Taksonomi Bloom Sebelum dan Sesudah di Revisi

Berikut tingkatan ranah kognitif revisi taksonomi bloom (Gunawan, 2016)

1. Remembering (mengingat) (C1) 
Pada tingkat ini mementingkan aspek ingatan, proses mengigat kembali terhadap materi-materi yang telah diberikan atau dipelajari, termasuk di dalamnya mengenali (recognizing), menuliskan atau menyebutkan (recalling).

2. Understanding (Memahami) (C2)

Pada tahap ini seseorang dapat menterjemahkan sesuatu, mengaitkan dengan pengetahuan yang telah dimiliki, atau mengintegrasikan pengetahuan yang baru ke dalam skema yang telah ada dalam pemikiran siswa.

3. Application (Mengaplikasikan) (C3)

Menerapkan merupakan mempergunakan suautu prosedur pada proses kognitif untuk menyelesaikan permasalahan.

4. Analyzing (Menganalisis) (C4)

Menganalisis berarti memecahkan permasalahan dengan mencari keterkaitan tiaptiap unsur atau bagian yang dapat menimbulkan permasalahan.

5. Evaluate (Mengevaluasi)

Mengevaluasi berarti memberi penilaian atau membuat pertimbangan berdasarkan standar dan kriteria yang ada.

6. Creating (Mencipta)

Mengkreasi atau mencipta yaitu reorganisasi unsur ke dalam pola atau struktur yang baru. Pada tingkat mengkreasi ini mengarah kepada proses berpikir kreatif. Effendi (2017) proses kreatif dapat dibedakan menjadi 3 fase yaitu a)representasi masalah, b) perencanaan solusi, c)pelaksanaan solusi.

Namun pada kenyataannya dilapangan hasil belajar peserta didik saat tatap muka terbatas masih sangatlah rendah, seperti nilai yang diperoleh kelas IX di SMP Terpadu Miftahul Khoir rata-rata penilaian Harian 72 dari KKM 75 dan persentase siswa yang nilainya dibawah KKM 64\%, artinya hanya sedikit siswa yang tuntas di pelajaran matematika pada tatap muka terbatas. Hasil PTS Semester genap diperoleh rata-rata nilai 67 dari KKM 75.

Hal tersebut bisa saja disebabkan oleh beberapa factor, baik factor internal dan eksternal. Menurut Akhirudiin (2019) Faktor Internal diantaranya 1) factor psikologis yang meliputi inetelegendi, bakat, dan motivasi; 2) factor fisologis seperti gangguan fisik, rasa malas, dan kehilangan konsentrasi pada pelajaran, sedangkan factor eksternal diantaranya 1) Faktor yang bersumber dari lingkungsn sekolah; 2) factor keluarga; 3)factor lingkungan masyarakat.

Dari hasil belajar siswa kelas IX di SMP Terpadu Miftahul Khoir dapat dipengaruhi oleh beberapa factor salah satunya factor lingkungan belajar, ada peserta didik yang mondok di pesantren ada juga siswa yang tidak mondok. Siswa yang sekaligus menjadi santri pondok pesantren tentu saja memiliki lingkungan yang berbeda dengan siswa yang tidak tinggal di pondok pesantren. Siswa yang tinggal di pondok pesantren biasanya memiliki aktivitas yang lebih padat, dan unsur yang ada di pondok pesantren tidak jauh berbeda dengan unsur yang ada di sekolah, keduanya merupkan Lembaga Pendidikan yang sama-sama punya peraturan dan kedisiplinan. 
Menurut Darmadi (2019). Lingkungan merupakan factor yang sangat penting yang berpengaruh terhadap perkembangan individu, yaitu berupa lingkungan fisik, linngkungan budaya, dan lingkungan sosial. Sedangkan (2019) mengemukakan lingkungan pendidikan dapat dibagi menjadi tiga baigan; 1) Lingkungan keluarga (informal); 2) Lingkungan Sekolah (formal); 3) Lingkungan masyarakat (informal). Ketiganya perlu berkolborasi dengan Lembaga Pendidikan diatas.

Pada penelitian ini untuk mengukur lingkungan belajar siswa, peneliti menggunakan indicator menurut Slameto (Hayati, 2017): 1) lingkungan keluarga, yang meliputi, hubungan antar anggota keluarga, suasana belajar dirumah, alat-alat, fasilitas, atau keadaan di dalam rumah dan ruang belajar; 2) lingkungan sekolah meliputi suasana pelaksanaan belajar mengajar, keadaan lingkungan sekolah, dan relasi antara warga sekolah; 3) lingkungan masyarakat meliputi kegiatan di dalam masayarakat, dan teman bergaul.

Berdasarkan latar belakang diatas, peneliti tertarik untuk menganalisis permasalahan pada hasil belajar matematika siswa kelas IX pembelajaran tatap muka terbatas (PTMT) siswa kelas IX yang ditinjau dari lingkungan belajar.

\section{METODE PELAKSANAAN}

Penelitian ini merupakan penelitian deskriptif dengan pendekatan kualitatif. Menurut Bogdan \& Taylor (Panjaitan, 2017)) penelitian kualitatif berusaha menghasilkan data deskriptif kualitatif berupa kata-kata tertulis atau lisan dari orang-orang dan perilaku yang diamati. Dalam penelitian ini data diperoleh dari hasil tes dan wawancara untuk menggali informasi terhadap apa yang dipikirkan dan dilakukan subjek.Lokasi yang dipilih pada penelitian ini adalah SMP Terpadu Miftahul Khoir, lingkungan SMP Terpadu Mifthaul Khoir berada satu kompleks dengan pondok pesantren, dimana ada sebagian siswa yang bersekolah tinggal di pesantren tersebut. Subjek penelitian ini adalah 2 orang siswa kelas IX yang memiliki kemampuan tinggi, rendah yang tinggal di lingkungan pondok pesantren, dan 2 orang siswa kelas IX yang memiliki kemampuan tinggi, rendah yang tidak tinggal di lingkungan pondok pesantren yang diambil dari nilai siswa yang didapat dari tes. Subjek penelitian yang dipilih adalah subjek yang dapat memberikan informasi sebanyak mungkin kepada peneliti, dan dapat mengkomunikasikan pikirannya sehingga peneliti bisa mengeksplorasi lebih dalam tentang subjek penelitian. Penetapan subjek penelitian ini dilakukan dengan memberikan tes matematika.

Teknik analisis data, yaitu dengan menelaah seluruh data yang tersedia dari berbagai sumber diantaranya dari wawancara, pengamatan, dan dari hasil tes yang sudah diberikan, reduksi data, penyajian data, dan penarikan kesimpulan.

\section{HASIL DAN PEMBAHASAN}

\subsection{Hasil}


1. Analisis Data Hasil Belajar

Pengumpulan data pada penelitian ini dengan menggunakan metode dokumentasi untuk mengambil soal ulangan harian dan hasil pekerjaan siswa kelas IX di SMP Terpadu Miftahul Khoir tahun ajaran 2021/2022 pada materi persamaan kuadrat sebanyak 6 soal uraian yang diberikan pada akhir pelajaran. Analisis data dilakukan dengan berpedoman pada ranah Taksonomi Bloom Revisi menurut Anderson dan Krathwohl. Berikut hasil belajar matematika siswa kelaas IX pada materi persamaan kuadrat disajikan pada Tabel 1.

Tabel 1. Hasil Belajar Siswa Berdasarkan Ranah Kognitif Taksonomi Bloom Revisi

\begin{tabular}{ccc}
\hline Nomor Soal & Ranah Kognitif & Persentase \\
\hline 1 & C3 & $3,33 \%$ \\
2 & C3 & 0 \\
3 & C4 & 0 \\
4 & C2 & $10,67 \%$ \\
5 & C2 & $6,67 \%$ \\
6 & C3 & 6 \\
\hline
\end{tabular}

Dari Tabel 1 terlihat bahwa sebagian besar siswa dapat menyelesaikan soal dengan indikator pemahaman, dan sebagian siswa juga dapat menyelesaikan soal pada indikator menerapkan, namun siswa belum mampu menyelesaikan soal dengan indikator menganalisis.

Hasil pengolahan data hasil belajar disajikan pada Tabel 2 dan Tabel 3 sebagai berikut:

Tabel 2. Distribusi frekuensi hasil belaja matematika

\begin{tabular}{ccccc}
\hline No & $\begin{array}{c}\text { kelas } \\
\text { interval }\end{array}$ & $\begin{array}{c}\text { Frekuensi nilai } \\
\text { (secara keseluruhan } \\
\text { kelas IX }\end{array}$ & $\begin{array}{c}\text { Frekuensi nilai siswa } \\
\text { yang tinggal di } \\
\text { pesantren }\end{array}$ & $\begin{array}{c}\text { Frekuensi nilai siswa } \\
\text { yang tidak tinggal di } \\
\text { pondok pesntren }\end{array}$ \\
\hline 1 & $0-11$ & 2 & 1 & 1 \\
2 & $12-22$ & 7 & 4 & 4 \\
3 & $23-33$ & 0 & 1 & 0 \\
4 & $34-44$ & 8 & 4 & 3 \\
5 & $45-55$ & 7 & 2 & 5 \\
6 & $56-66$ & 1 & 0 & 1 \\
\hline
\end{tabular}

Tabel 3. Deskripsi data hasil belajar matematika

\begin{tabular}{lc}
\hline $\mathrm{n}$ & 25 \\
Mean & 32,4 \\
median & 35 \\
modus & 48 \\
Sdi & 15,89811 \\
$\max$ & 60 \\
$\min$ & 0 \\
\hline
\end{tabular}


Berdasarkan Tabel 2 tentang distribusi frekuensi dapat diketahui bahwa frekuensi tertinggi perolehan skor hasil belajar siswa berada pada kelas 34-44 dengan jumlah 8 orang siswa. Dengan sebaran data berada pada interval 34-33, hal tersebut berdasarkan median dan modus yang diperoleh. Untuk standar deviasi 15,9, lebih kecil daripada rata-rata yaitu 32,4. Hal ini berarti darat bersifat homogen. Jika dilihat dari rata-rata hasil belajar siswa yaitu 32,4, sedangkan KKM yang ditentukan di sekolah yaitu 75 , seluruh siswa diktakan belum mampu mencpi nilai target yang di tetapkan.

Dari penelitian tersebut diperoleh bahwa secara keseluruhan terdapat 15 orang di kelas IX yang nilainya diatas rata-rata. Jika dilihat dari lingkungan tempat tinggalnya, terdapat 6 orang siswa yang tinggal di pondok pesantren yang nilainya di atas rata-rata, dan 9 orang siswa yang tidak tinggl di pondok pesantren memiliki nilai di atas rata-rata.

\section{Lingkungan Belajar}

Perolehan data untuk variable lingkungan belajar diperoleh dengan menggunakan angket dengan skala likert sebanyak 20 butir pernyataan, dengan indicator : 1 . lingkungan rumah : hubungan antar keluarga, suasana belajar, alat-alat belajar, dan tempat belajar; 2. Lingkungan sekolah : sekolah, dan teman bergaul. Analisis angket lingkungan belajar peserta didik dilakukan dengan menghitung jumlah skor terlebih dahulu kemudian dihitung, diperoleh hasil data seperti berikut:

Tabel 4. Distribusi frekuensi lingkungan belajar secara keseluruhan

\begin{tabular}{ccccccccc}
\hline No & skor & $\mathrm{f}$ & $\%$ & $\begin{array}{c}\text { Frekuensi } \\
\text { (siswa yang } \\
\text { tinggal di } \\
\text { ponpes) }\end{array}$ & persentase & $\begin{array}{c}\text { Frekuensi } \\
\text { (siswa yang } \\
\text { tidak tinggal } \\
\text { di ponpes) }\end{array}$ & kategori \\
\hline 1 & $\mathrm{X} \leq 40$ & 0 & $0 \%$ & 0 & 0 & 0 & 0 & rendah \\
2 & $40<\mathrm{X}<60$ & 6 & $24 \%$ & 0 & 0 & 6 & 47 & sedang \\
3 & $60 \geq \mathrm{X}$ & 19 & $76 \%$ & 12 & 100 & 7 & 53 & tinggi \\
\hline
\end{tabular}

Tabel 4 menunjukkan bahwa 6 dari 25 orang berada di lingkungan belajar dengan kategori sedang dengan persentase 24\%, dan 19 orang dari 25 orang berada pada lingkungan belajar dengan kategori tinggi dengan persentase $76 \%$. Untuk siswa yang berada di lingkungan pondok pesantren sebanyak 12 orang dengan kategori tinggi, hal ini mungkin saja disebabkan oleh fasilitas, tempat belajar, dan waktu belajar yang dimiliki siswa sama karenaa berada dilingkungan yang sama. Sedangkan sebanyak 7 orang siswa yang tidak tinggal di lingkungan pondok pesantren yang termasuk kategori tinggi, dan 6 orang siswa yang termsuk pada kategori sedang, artinya lingkungan belaajar siswa sudah cukup baik, mungkin saja bisa terjadi karena lingkungan rumah, lingkungan masyarakat serta teman bergaul nya berbeda sehingga dapat mempengaruhi kepada kesehaarian peserta didik dan kegiatan belajar peserta didik. 
Analisis data angket lingkungan belajar untuk setiap indikator disajikan pada Tabel 5 sebagai berikut.

Tabel 5. Analisis data lingkungan belajar setiap indikator

\begin{tabular}{clccl}
\hline No & \multicolumn{1}{c}{ indikator } & jumlah butir & $\mathrm{X}$ & kategori \\
\hline 1 & lingkungan rumah (keluarga) & 2 & 2,6 & sedang \\
2 & lingkungan rumah (tempat belajar) & 3 & 2,8 & sedang \\
3 & lingkungan rumah (suasana belajar) & 3 & 2,9 & sedang \\
4 & lingkungan rumah (alat-alat belajar) & 5 & 2,7 & sedang \\
5 & lingkungan sekolah (sekolah) & 3 & 3,1 & tinggi \\
6 & lingkungan sekolah (teman bergaul) & 4 & 2,7 & sedang \\
\hline
\end{tabular}

Skor tertinggi terdapat pada indicator lingkungan sekolah, yaitu aktivitas peserta didik dan guru atau interaksi antar siswa dan guru pada saat di sekolah khususnya disaat pembelajaran berlangsung sudah baik meskipun pembelajarannya masih secara terbatas dimasa pandemic covid-19 ini. Skor terendah yaitu pada indicator lingkungan rumah pada hubungan antar keluarga dengan perolehan skor 2,6, meskipun berada pada kategori sedang namun hal tersebut menunjukkan bahwa orang tua atau keluarga memiliki pengaruh yang besar terhadap prestasi belajar siswa, artinya peserta didik masih perlu bimbingan, arahan, dan motivasi dari orang tua atau keluarga untuk kegiatan belajarnya. Untuk indicator lingkungan rumah berupa alat-alat belajar siswa berada pada kategori sedang, artinya sudah cukup baik fasilitas belajar yang dimiliki siswa baik di sekolah ataupun dirumah, namun dari beberapa jawaban pernyataan angket beberapa siswa menjawab bahwa ia cenderung menggunakan gawai bukan untuk belajar.

\subsection{Pembahasan}

Selanjutnya dilakukan analisis terhadap hasil pekerjaan siswa untuk mengatahui tingkatan kognitif siswa menurut taksonomi bloom revisi. Dari 25 orang siswa kelas IX diambil 2 orang siswa yang tinggal di pondok pesantren dengan kategori tinggi, dan rendah, dan 2 orang siswa yang tidak tinggal di pondok pesantren dengan kategori tinggi, dan rendah. Kategori tersebut dilihat berdasarkan nilai yang di dapat dari tes.

1. Hasil Belajar Matematika Dengan Kategori Tinggi

a. Hasil Belajar Matematika yang tinggal di pondok pesantren dengan kategori tinggi (S1)

Berikut disajikan hasil pekerjaan subjek 1 terkait soal persamaan kuadrat pada gambar 1. Soal yang digunakan untuk menganalisis kemampuan memahami yang disajikan pada soal nomor 4, dan 5 adalah sebagai berikut:

Soal nomor 4 dan 5

4. Tentukan akar persamaan kuadrat dari persamaan berikut: $x^{2}+7 x+6=0$ 
5. Nyatakan persamaan $3\left(x^{2}+1\right)=x(x-3)$ dalam bentuk umum persamaan kuadrat!
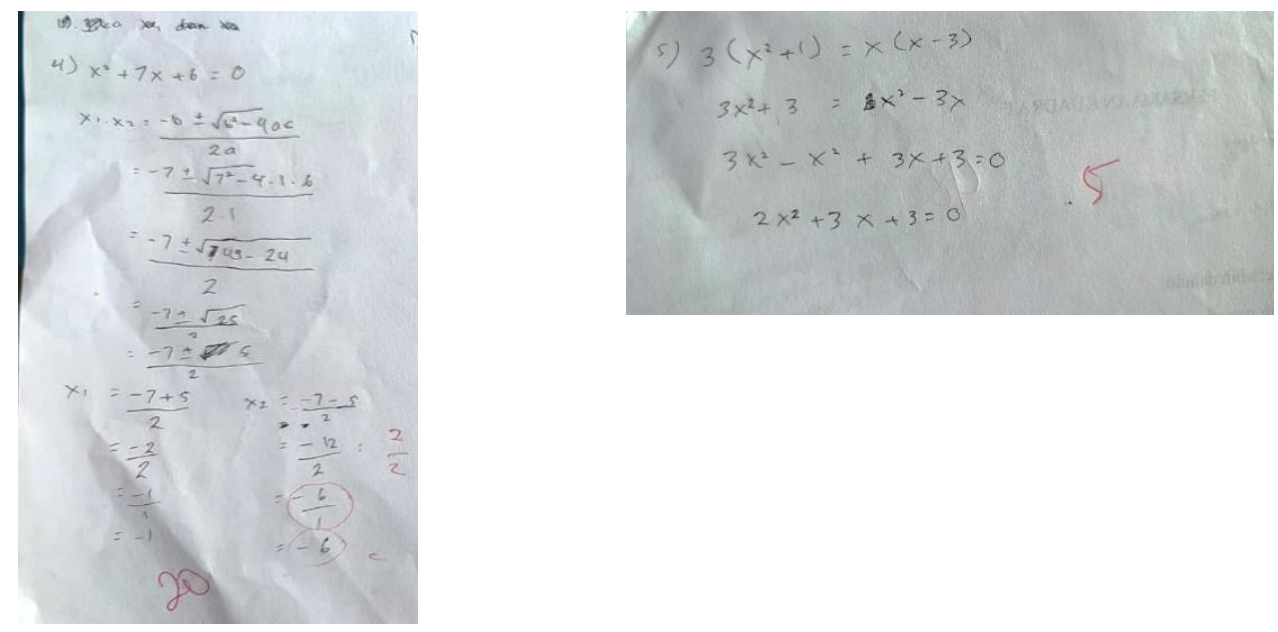

Gambar 2. Hasil Jawaban Siswa S1 Untuk Indikator Memahami

Indikator memahami sudah dicapai oleh siswa $\mathrm{S} 1$, karena siswa tersebut mampu menjawab soal nomor 4 dan 5 dengan benar,

Indikator menerapkan terdapat pada soal nomor 1,2 , dan 6 , dengan soal sebagai berikut:

1. Jika $x_{1}$ dan $x_{2}$ adalah penyelesaian dari $4 x^{2}+8 x-5=0$ dan $x_{1}>x_{2}$ nilai dari $x_{1}-x_{2}$ adalah ...

2. Sebuah taman bunga yang dibentuk untuk mengurangi polusi udara di kota berbentuk persegi Panjang. Teman tersebut mempunyai keliling $100 \mathrm{~m}$ dan Luas $400 \mathrm{~m}^{2}$. Berapa selisih Panjang dan lebarnya?

6. Jika nilai diskriminan persamaan kuadrat $3 x^{2}-5 x+c=0$ adalah 49, Berapa nilai c agar persamaan tersebut menjadi persamaan kuadrat! 


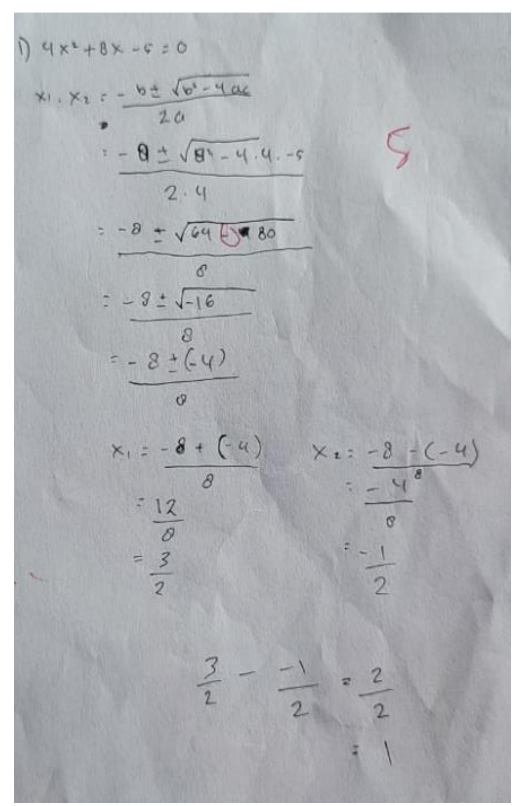

Gambar 3. Hasil Jawaban Siswa S1 untuk Indicator Menerapkan

Untuk soal nomor 1 dengan indicator menerapkan siswa $\mathrm{S} 1$ belum mampu menjawab soal dengan tepat, siswa S1 sudah mengetahui konsep nya namun dalam perhitungan siswa S1 kurang teliti yang menyebabkan adanya salah perhitungan. Menurut siswa S1 jika soalnya sudah menerapkan dan dikaitkan dengan masalah sehari-hari siswa merasa kebingungan untuk menyelesaikannya.

Peneliti juga mewawancara siswa S1 untuk mengetahui terkait lingkungan belajarnya yang mana siswa S1 tinggal di lingkungan pondok pesantren. Menurut siswa S1 lingkungan belajar di rumah (hubungan keluarga) sudah baik, suasana belajar sudah baik, namun untuk fasilitas belajar dan tempat belajar belum sepenuhnya mendukung terhadap pembelajaran, dan menurut siswa S1 pada pembelajaran tatap muka terbatas ini memiliki kekurangan yaitu terbatasnya waktu sehingga siswa S1 merasa kurang puas dalam belajar sehingga hasil belajar yang diperolehnya menurutnya belum memuaskan.

b. Hasil Belajar Matematika yang tidak tinggal di pondok pesantren dengan kategori tinggi (S2)

Berikut disajikan hasil pekerjaan subjek 2 terkait soal persamaan kuadrat untuk soal nomor 4 dan 5 dengan indicator memahami pada Gambar 4.
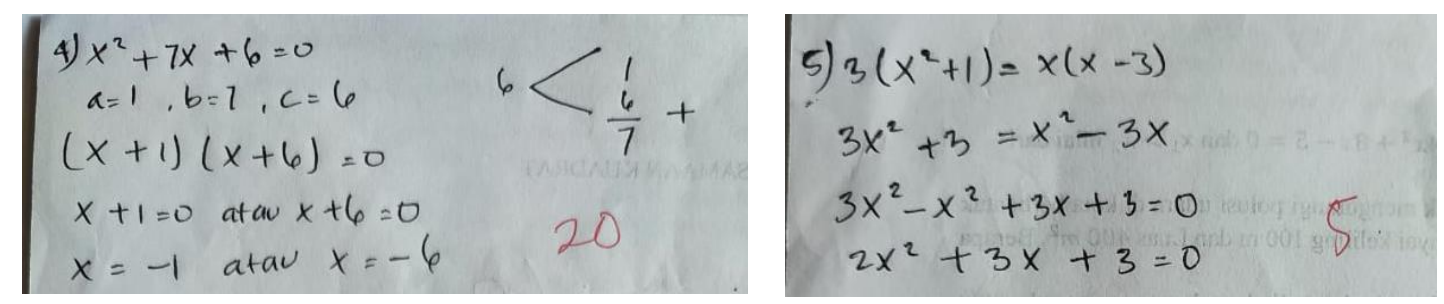

Gambar 4. Hasil Jawaban Siswa S2 Untuk Indikator Memahami 
Berdasarkan jawaban pada nomor soal 4 dan 5, siswa S2 sudah menjawab soal dengan tepat, artinya ranah kognitif siswa S2 untuk indicator memahami sudah baik. Sedangkan untuk hasil jawaban siswa dengan indicator menerapkan terdapat pada Gamabr 5 berikut ini.
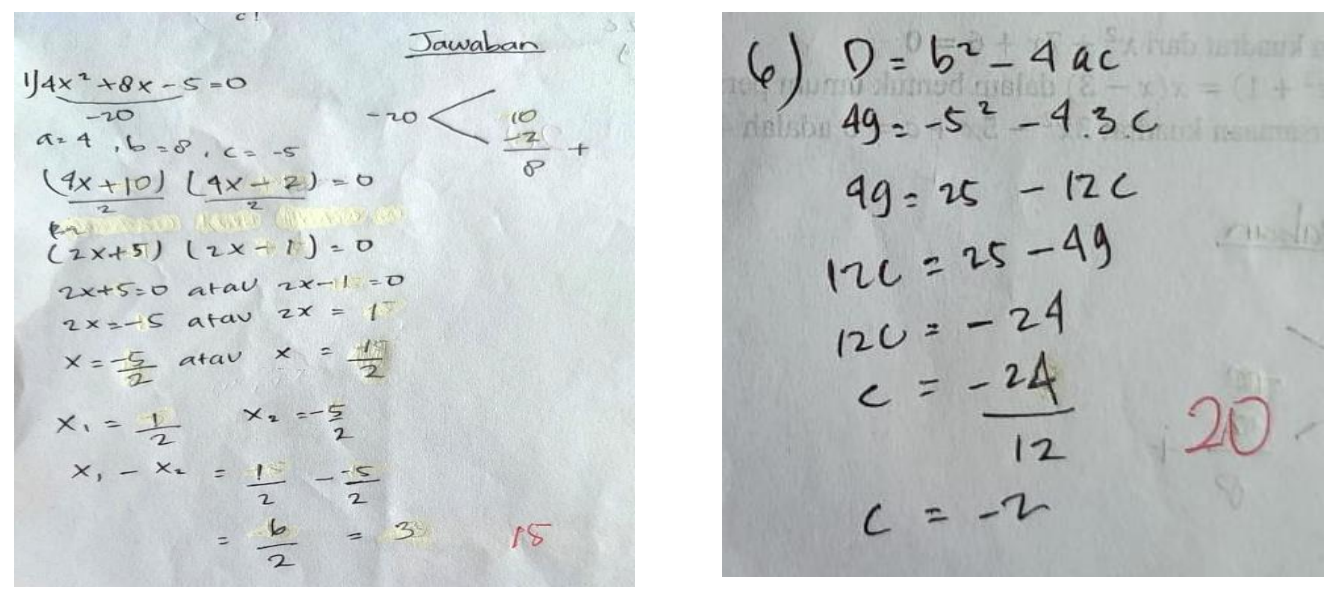

Gambar 5. Hasil Jawaban Siswa S2 Untuk Indikator Menerapkan

Dari gambar 5, di ketahui indikator menerapkan terdapat pada soal nomor 1,2, dan 6 , namun siswa S2 hanya mampu mengerjakan soal nomor 1 dan 6 dengan tepat. Menurut siswa S2 mengalami kesulitan jika soal tersebut merupakan soal tidak rutin atau jika soalnya berbeda dengan contoh yang diberikan guru apalagi jika soalnya merupakan soal yang dihubungkan dengan kehidupan sehar-hari dan harus dihubungkan dengan konsep lain seperti soal nomor 6 .

Berdasarkan hasil angket dan wawancara tentang lingkungan belajar untuk siswa S2 sudah baik namun siswa S2 memiliki kesulitan pada pembelajaran matematika yaitu siswa S2 kesulitan mengerjakan soal jika soal tersebut berbeda dengan contoh yang diberikan, siswa juga kurang puas belajar di kelas karena jam nya terbatas, namun siswa S2 selalu memanfaatkan fasilitas yang ada di rumah untuk mempelajari lagi materi sehingga hasil belajar siswa S2 mempunyai nilai tertinggi.

\section{Hasil Belajar Matematika Dengan Kategori Rendah}

a. Hasil Belajar Matematika yang tinggal di pondok pesantren dengan kategori rendah (S3)

Berikut disajikan hasil pekerjaan subjek 3 terkait soal persamaan kuadrat. 


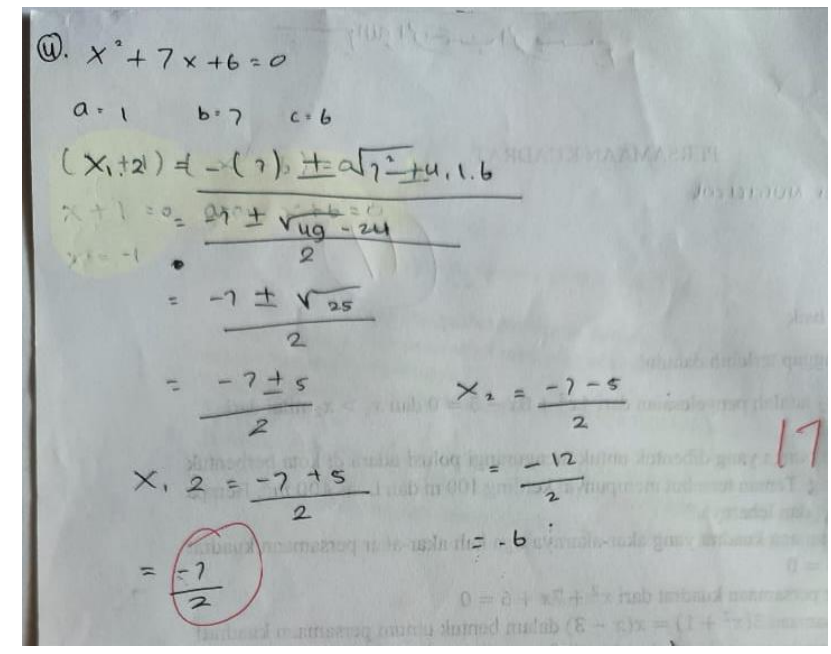

Gambar 6. Hasil Jawaban Siswa S3 Untuk Indikator Memahami

Siswa S3 hanya nomor 4 saja dengan indicator memahami, siswa S3 sudah memahami soal dengan baik namun ada kesalahan dalam penyelesaiannya, artinya S4 tidak mencapai indicator menerapkan dan menganalisis, karena menurut siswa S3 kesulitan yang dialami yaitu sulit menghafal rumus dan menerapkannya jika ada soal yang berbeda dan menurut siswa S3 matematika itu sulit.

Berdasarkan wawancara dan hasil tes soal matematika, siswa S3 menurutnya lingkungan belajar sudah baik, dukungan dari orang tua sudah baik, namun dirinya mengalami kesulitan yaitu membagi waktu belajar, karena harus membagi waktu dengan kegiatan yang ada di pesantren, dan siswa S3 belum menggunakan fasilitas yang ada dengan baik, seperti tidak menggunakan hp untuk kepentingan belajar, karena menurut siswa S3 matematika itu sulit sehingga nilai belajar nya pun rendah.

b. Hasil Belajar Matematika yang tidak tinggal di pondok pesantren dengan kategori rendah (S4)

Berikut disajikan hasil pekerjaan subjek 4 terkait soal persamaan kuadrat. 


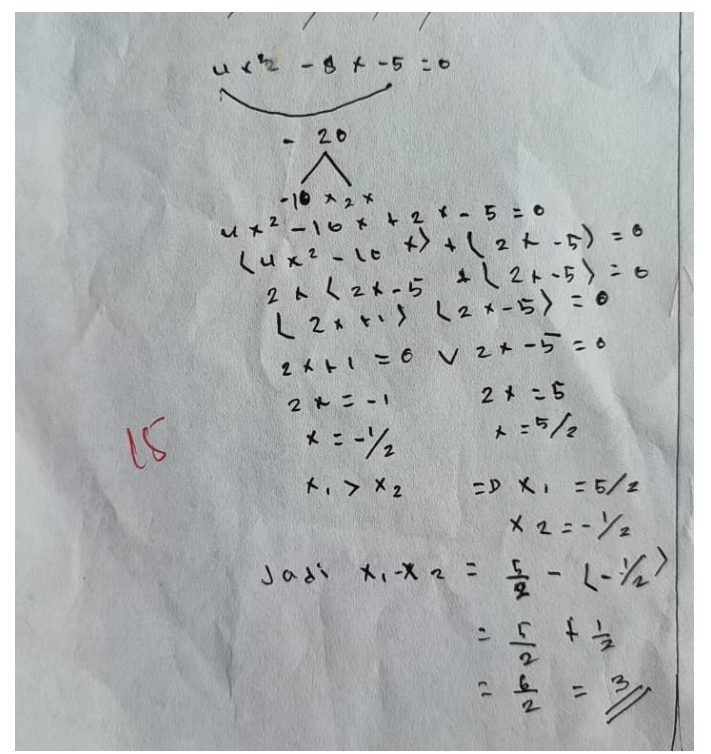

Gambar 7. Hasil Jawaban Siswa S3 Untuk Indikator Menerapkan

Siswa S4 hanya mampu menyelesaiakan 1 soal yaitu soal nomor satu dengan indicator menerapkan. Dari jawaban siswa S4 maka siswa tersebut belum bisa mencapai indicator memahami S2 dan belum sepenuhnya bisa mengerjakan soal dengan indicator menerapkan.

Kemudian dari hasil wawancara terkait lingkungan belajar siswa S4, menurutnya dukungan, motivasi dari orang tua sudah baik, perhatian dan cara mengajar guru sudah baik, namun iswa S4 lebih menyukai guru memakai metode ceramah karena menurutnya lebih paham, ruangan belajar di sekolah dan di rumah sudah baik, namun siswa S4 tidak menggunakan fasilitas dengan baik, dan siswa $\mathrm{S} 4$ lebh senang bermain dengan teman daripada belajar, karena menurut siswa S4 matematika itu susah sehingga siswa S4 mempunyai hasil belajar yang rendah.

Dari hasil tes, angket, dan wawancara, dapat disimpulkan bahwa lingkungan belajar sangat berpengaruh terhadap hasil belajar siswa, secara keseluruhan dari indicator lingkungan rumah dan sekolah sudah baik, tetapi untuk fasilitas belajar perlu di optimalkan lagi untuk mendukung pembelajaran matematika, selain itu siswa juga mengeluhkan waktu belajar yang terbatas yang menjadi salah satu faktor rendahnya hasil belajar di masa pandemic covid-19 ini, sejalan dengan Onde (2021) Dampak bagi guru pada Pembejaran TMT yaitu; 1) waktu yang sangat terbatas, 2) guru sangat kesulitan dalam mengelola pembelajaran karena guru cenderung focus pada penuntasan kurikulum, sementara waktunya terbatas. Sementara masalah pembelajaran TMT bagi siswa diantaranya : 1) harus membatasi interaksi sosial 2) mengeluhkan penugasan yang diberikan dari guru yang dirasa berat oleh peserta didik, 3) peningkatan rasa stress dan jenuh karena pembatasan aktivitas selama di sekolah, 4) kurangnya partisipasi aktif dari siswa, karena pembelajaran di dominasi oleg guru.

\section{SIMPULAN}

Berdasarkan hasil penelitian dan pembahasan maka diperoleh beberapa kesimpulan berikut : (1) soal yang diberikan tentang materi persamaan kuadrat berdasarkan Taksonomi Bloom Revisi, siswa kelas IX lebih mampu menyelesaikan soal dengan 
indicator memahami sebesar $10,67 \%$ dan 6,67\%, daripada soal dengan idnikator menerapkan yang hanya $3,33 \%$ dann $6 \%$. Dimana siswa dengan kemampuan tinggi sudah mencapai indicator memahami dan menerapkan, hanya saja siswa dengan kemampuan tinggi belum mampu menyelesaikan soal indicator menerapkan non rutin, dan siswa dengan kemampuan rendah tidak mampu mengerjakan soal dengan indicator memahami dan menerapkan dengan baik (2) lingkungan belajar siswa kelas IX berada pada lingkungan belajar pada kategori tinggi dengan persentase $76 \%$, dan dengan kategori sedang 24\%. Dimana siswa dengan kemampuan tinggi maupun rendah sudah memeiliki lingkungan belajar yang baik, namun dari jawaban siswa, siswa belum menggunakan fasilitas belajar dengan baik, dan dilihat dari indicator teman bergaul, siswa belum berinisiatif untuk mengajak temannya berdiskusi dan hanya menunggu perintah dari guru untuk berdiskusi.

Meskipun factor lingkungannya sudah baik mungkin ada factor lain yang mempengaruhi hasil belajar siswa seperti terbatasnya waktu terutama dimasa pandemic covid-19 ini.

\section{REFERENSI}

Akhiruddin., Sujarwo., Atmowardoyo, H., Nurhikmah. (2019). Belajar dan Pembelajaran. Gowa : CV. Cahaya Bintang Cemerlang.

Anderson, L.W., dan Krathwohl, D.R. (2001). A Taxonomy for Learning, Teaching, and Assesing: A Revision of Bloom's Taxonomy of Educatioanl Objectives. New York: Addison Wesley Longman, Inc

Basar, A. M. (2021). Problematika Pembelajaran Jarak Jauh Pada Masa Pandemi Covid-19 : (Studi Kasus di SMPIT Nurul Fajri-Cikarang Barat-Bekasi). Edunesia : Jurnal Ilmiah Pendidikan, 2 (1), 208-218. doi:10.51276/edu.v2i1.112

Djamaludin, A \& Wardhana. (2019). Belajar dan Pembelajaran. 4 Pilar Peningkatan Kompetensi Pedagogis. Parepare: CV. Kaffah Learning Center

Effendi, R. (2017). Konsep revisi taksonomi Bloom dan implementasinya pada pelajaran matematika SMP. JIPMat, 2(1).Thesis and dissertation, research reports: Susiswo. (2006). Folding Back Mahasiswa dalam Menyelesaikan Masalah Limit. Doctoral dissertation. Universitas Negeri Malang.

Fadilla, A. N., Relawati, A. S., \& Ratnaningsih, N. (2021). Problematika Pembelajaran Daring Pada Pembelajaran Matematika Di Masa Pandemi Covid-19. Jurnal Jendela Pendidikan, 1(02), 48-60.

Gunawan, I., \& Palupi, A. R. (2016). Taksonomi Bloom-revisi ranah kognitif: kerangka landasan untuk pembelajaran, pengajaran, dan penilaian. Premiere educandum: jurnal pendidikan dasar dan pembelajaran, 2(02).

Hamid Darmadi. (2019). Pengantar Pendidikan Era Globalisasi: Konsep Dasar, Teori, Stategi, dan implementasi dalam Pendidikan Global. Jakarta: An1mage

Hayati, S. (2017). Belajar \& Pembelajaran Berbasis Cooperative Learning. Yogyakarta: Graha Cendekia

Keputusan Bersama Menteri Pendidikan dan Kebudayaan, Menteri Agama, Menteri Kesehatan, dan Menteri Dalam Negeri Republik Indonesia. (2021). Nomor 03/KB/2021, Nomor 384 Tahun 2021, Nomor HK.01.08/MENKES/4242/2021, Nomor 440-717 tentang Panduan Penyelenggaraan Pembelajaran di Masa Pandemi COVID-19 
Nissa, S. F., \& Haryanto, A. (2020). Implementasi Pembelajaran Tatap Muka Di Masa Pandemi Covid-19. Jurnal IKA PGSD (Ikatan Alumni PGSD) UNARS, 8(2), 402-409.

Nurhasanah, S., \& Sobandi, A. (2016). Minat belajar sebagai determinan hasil belajar siswa. Jurnal Pendidikan Manajemen Perkantoran (JPManper), 1(1), 128-135.

Onde, M. K. L. O., Aswat, H., Sari, E. R., \& Meliza, N. (2021). Analisis Pelaksanaan Pembelajaran Tatap Muka Terbatas (TMT) di masa New Normal terhadap Hasil Belajar Matematika di Sekolah Dasar. EDUKATIF: JURNAL ILMU PENDIDIKAN, 3(6), 44004406

Panjaitan, Roimanson. (2017). Metodologi Penelitian. Kupang : Jusuf Aryani Learning.

Sudjana, N. (1995). Penilaian hasil proses belajar mengajar. 